\title{
Package Handling Code
}

National Cancer Institute

\section{Source}

National Cancer Institute. Package Handling Code. NCI Thesaurus. Code $C 95366$.

A coded value specifying handling requirements for a package. 